\title{
Post-harvest deterioration of green billeted and green whole stalk sugarcane in Northeast Thailand
}

\section{Rattana Mueangmontri, Pisittinee Chapanya and Anutin Pattamasuwan}

Department of Biotechnology,

Kasetsart University,

Bangkok 10900, Thailand

and

Mitrphol Innovation and Research Center Co., Ltd.,

Phu Khiao, Chaiyaphum 36100, Thailand

Email: rattanam@mitrphol.com

Email: pisittineec@mitrphol.com

Email: anutinp@mitrphol.com

\section{Klanarong Sriroth}

Mitrphol Innovation and Research Center Co., Ltd., Phu Khiao, Chaiyaphum 36100, Thailand

Email: klanarongs@mitrphol.com

\section{Prakit Sukyai*}

Biotechnology of Biopolymers and Bioactive

Compounds Special Research Unit,

Department of Biotechnology,

Faculty of Agro-Industry,

Kasetsart University,

Chatuchak, Bangkok 10900, Thailand

Email: fagipks@ku.ac.th

*Corresponding author

\begin{abstract}
This study considered post-harvest deterioration of green billeted and green whole stalk on sugarcane. A yield deterioration assessment was conducted in the Northeast of Thailand. To have an appropriate assessment, several sugarcane quality parameters such as sugarcane weight $(\mathrm{kg})$, Brix \%, juice purity $\%$, commercial cane sugar (CCS) \% of cane, reducing sugar $\%$ Brix, mannitol, lactic acid, and dextran in $\mathrm{mg} / \mathrm{kg}$ Brix unit were used to investigate post harvest sugarcane deterioration due to bacterial activity. The deterioration trial was undertaken over 13 days to investigate the green billets (GB) and green whole-stalks (GWS). All sugarcane quality parameters, CCS $\%$, reducing sugar $\%$ Brix and juice purity $\%$ showed a faster deterioration rate of GB than GWS under identical time and climatic conditions. Mannitol, lactic acid and dextran were useful as an indicator of deterioration and estimating the juice purity drop during post-harvest sugarcane deterioration.
\end{abstract}


Keywords: post-harvest deterioration; green sugarcane; mannitol; lactic acid; green billets sugarcane; Thailand.

Reference to this paper should be made as follows: Mueangmontri, R., Chapanya, P., Pattamasuwan, A., Sriroth, K. and Sukyai, P. (2020) 'Post-harvest deterioration of green billeted and green whole stalk sugarcane in Northeast Thailand', Int. J. Postharvest Technology and Innovation, Vol. 7, No. 1, pp.29-41.

Biographical notes: Rattana Mueangmontri is a Master's student in the Department of Biotechnology, Kasetsart University, Thailand. She is also working as a researcher in the Mitrphol Innovation and Research Center Co., Ltd., Phu Khiao, Chaiyaphum, Thailand. She is currently in a research on dextran and sugarcane deterioration in sugar process project.

Pisittinee Chapanya is a Master's student in the Department of Biotechnology, Kasetsart University, Thailand. She is also working as a researcher in the Mitrphol Innovation and Research Center Co., Ltd., Phu Khiao, Chaiyaphum, Thailand. She is currently in a research on application of near infrared spectroscopy (NIR) for sugar and mineral predictions in Molasses project.

Anutin Pattamasuwan is working as the Senior Manager in the Sugar Technology Department of Mitrphol Innovation and Research Center Co., Ltd., $\mathrm{Phu}$ Khiao, Chaiyaphum, Thailand. She is currently in a research to improve on sugar mill efficiency.

Klanarong Sriroth is an Associate Professor at the Department of Biotechnology, Faculty of Agro-Industry, Kasetsart University, Thailand. He is also working as the Board of Director in the Mitrphol Innovation and Research Center Co., Ltd., Phu Khiao, Chaiyaphum, Thailand.

Prakit Sukyai is an Assistant Professor of the Department of Biotechnology, Faculty of Agro-Industry, Kasetsart University, Thailand. He is also working in the Biotechnology of Biopolymers and Bioactive Compounds Special Research Unit, Department of Biotechnology, Faculty of Agro-Industry, Kasetsart University.

\section{Introduction}

Sugarcane harvesting season in Thailand is generally from November to April (Sukyai et al., 2016), and about $66 \%$ of sugarcane is mainly harvested by manpower after burning, while the rest $34 \%$ is done by mechanisation recently increased. Sugarcane plantation area in the 2017/2018 harvesting year has been reported as the largest area in the Northeast region, around $43 \%$ of the total sugarcane planting area followed by $25.5 \%$, $27 \%$ and $5 \%$ in North, Central and East regions, respectively. Khonkaen 3 (KK3) is the main variety in Northeast Thailand and accounted for $80 \%$ of the sugarcane plantation. Harvesting method in the region consisted of approximately $41.5 \%$ of the sugarcane been harvested as green cane and the rest $58.5 \%$ as a burnt cane (Anonymous, 2018). 
Sugarcane deterioration after harvesting can be a problem as a result of the high temperature and humidity during the crushing season. Therefore, a delay of cut to crush processing has been investigated. Lionnet (1986) showed that harvest-to-crush durations have direct effects on the quality of sugarcane such as the reduction of sucrose contents due to microbial utilisation and increased the rate of purity drop. Eggleston (2002) studied the deterioration of sugarcane juice by simulating juice at $27^{\circ} \mathrm{C}$ for 71 hours. It was found that sucrose loss was mainly caused by microbiological activity (93\%). In addition, many parameters have been used recently to determine bacterial activity including mannitol, isomaltotriose, 1-kestose and 6-kestose. Interestingly, mannitol serves as a good parameter to indicate sugarcane juice deterioration resulting from Leuconostoc bacteria. It was used as the criterion to determine sugarcane deterioration with freezing in sugarcane varieties for cold conditions (Eggleston and Legendre, 2003).

Petit et al. (2009) studied sugarcane deterioration in Reunion Island where the whole stalk of sugarcane was stored and analysed every two days. They found that the concentrations of 1-kestose, amino acids and aconitic acid correlated with length of the delay. Bhatia et al. (2009) reported that during 12 days of study, sugarcane weight, juice extraction, sucrose \% in juice, purity, and $\mathrm{pH}$ continuously decreased while total soluble solid (TSS), reducing sugars, dextran and acid invertase increased continuously. Another study by Datir and Joshi (2015), also shown the effect of different crushing and harvesting time on sugarcane quality from green billets (GB) and green sugarcane whole stalk harvesting methods after 72 hours of deterioration time.

The post-harvest sugarcane deterioration products are affected by many factors including harvesting method, variety, crop maturity, cut to crush period, ambient temperature, humidity and sugarcane logistic system (Eggleston et al., 2008; Solomon, 2009). Many sugarcane deterioration products were studied in different countries and climatic conditions. There are many metabolites which are used to monitor the sugarcane deterioration, these include dextran, mannitol, lactic acid, ethanol, and ketoses, with different deterioration mechanism. The dextran is polysaccharide produces by lactic acid bacteria which results in needle formation of sugar crystal. Dextran detection is laborious and time-consuming therefore, an indirect method has been introduced for its detection. Eggleston et al. (2008) reported that mannitol and lactic acid can be used as a sugarcane deterioration indicator which is related to dextran formation.

This study aimed to determine the effects of post-harvest handling on sugarcane quality. The delay of cut to crush was simulated under Northeast Thailand climatic conditions and the changes of biochemical parameters have been investigated. Therefore, this could be a realistic model for Asian countries about the effect of cut to crush delay and using bacterial metabolites as an indicator of sugarcane deterioration.

\section{Materials and methods}

\section{Materials}

The reagents and solvents; sucrose, fructose, glucose, and mannitol were purchased from Sigma Aldrich Co. Ltd. (St. Louis, MO) and Sugarcane Chaiyaphum Province, Thailand. All chemicals are of analytical grade. 


\subsection{Sugarcane preparation}

The sugarcane harvesting was conducted using 12 months old KK3 variety grown at Chaiyaphum Province, Thailand. The experiments were conducted from 14-27 March 2017 at Mitr Phol Innovation and Research Center Co., Ltd., Phu Khieo, Chaiyaphum Province.

Green whole stalk (GWS) was laid on the ground and divided into six piles (six stalks each). Three samples were randomly allocated to each of the 13 deterioration days and each subsample was weighed. For GB, $6 \mathrm{~kg}$ of GB were randomly discharged from the harvester bin into 60 labelled containers and left on the field. The weight of sugarcane and quality parameters were determined for 13 days. The GWS and GB samples were shredded separately, and $500 \mathrm{~g}$ was used to analysis fibre \% in cane. Another $2.5 \mathrm{~kg}$ was pressed by a sugarcane press at $19,000 \mathrm{kPa}$ for the $40 \mathrm{~s}$. All juices were collected and analysed for pol, Brix, sucrose, glucose, fructose, reducing sugar, mannitol, lactic acid and dextran as follows.

\subsection{Sugarcane quality analyses}

\subsubsection{Pol and Brix analyses}

Pol and Brix were determined using the International Commission for Uniform Methods of Sugar Analysis (ICUMSA, 1994) methods. $200 \mathrm{ml}$ of cane juice was mixed with 1.5 gram filter aid and filtered by vacuum. The filtrates were used for pol reading by polarimeter (Polartronic MH8, Schmidt Haensch, Germany) at $20^{\circ} \mathrm{C}$ and calculated pol \% of cane. Brix was measured by automatic table refractometer, ATR-SW at $20^{\circ} \mathrm{C}$.

\subsubsection{Carbohydrates analysis}

Sucrose, glucose, fructose, and mannitol were determined by high-performance liquid chromatography (HPLC), Shimazu LC-20 AD, with a refractive index detector. Water Sugar Pak column using $0.05 \%$ Ca-EDTA as a mobile phase and $20 \mu \mathrm{l}$ was injected for 20 minutes of run time at $80^{\circ} \mathrm{C}$ in a column oven at a flow rate of $0.5 \mathrm{ml} / \mathrm{minute}$. The amount of sugar was quantified using the sugar standard mixtures containing $0.5 \%$ sorbitol as an internal standard. A standard curve, the relative error of known samples, recovery and precision in juices were determined. The sugarcane juice sample was diluted to an appropriate concentration and filtered through a $0.45 \mu \mathrm{m}$ membrane.

\subsubsection{Lactic acid analysis}

The lactic acid content in sugarcane juice was determined by an HPLC, Shimazu LC-20 AD, refractive index detector, waters C18 column, $5 \mu \mathrm{m}, 416 \mathrm{~mm} \times 250 \mathrm{~mm}$ and $20 \mu \mathrm{l}$ was injected for 30 minutes into the column using $5 \mathrm{mM} \mathrm{H}_{2} \mathrm{SO}_{4}$ as a mobile phase at $0.6 \mathrm{ml} /$ minute of flow rate at $30^{\circ} \mathrm{C}$ in a column oven. A standard curve, the relative error of known samples, recovery and precision in juices were determined. The sugarcane juice sample was diluted to an appropriate concentration, and filtered through a $0.45 \mu \mathrm{m}$ membrane. 


\subsubsection{Dextran analysis}

Dextran was measured by the Modified Method II [adapted from ICUMSA Method GS1-15 (1994) and Eggleston and Monge (2005)].

\subsection{Experimental design and climatic information}

The experiment was conducted in March 2017 in the Northeast of Thailand. The experimental design was a randomised complete block with three replications. The sampling method was done in triplicate and each sample analysed. Climatic information consists of daily temperature minimum, maximum, average and humidity, obtained from a nearby weather station. The average variables were compared between treatments by Duncan's multiple range test (DMRT).

\section{Results and discussion}

\subsection{Sugarcane weight loss}

GB and GWS were kept for 13 days and the daily temperature values are presented in Table 1 together with the daily rainfall. The temperature range was from 20.9 to $40.6^{\circ} \mathrm{C}$ and the daily rainfall ranged from 0 to $105.9 \mathrm{~mm}$. The percentage of cane weight loss has increased after 13 days, resulting from the evaporation of water in cane. GB showed higher weight loss than GWS due to the open surface of the cane billet.

Figure 1 Relation between cane weight and post-harvest days (see online version for colours)

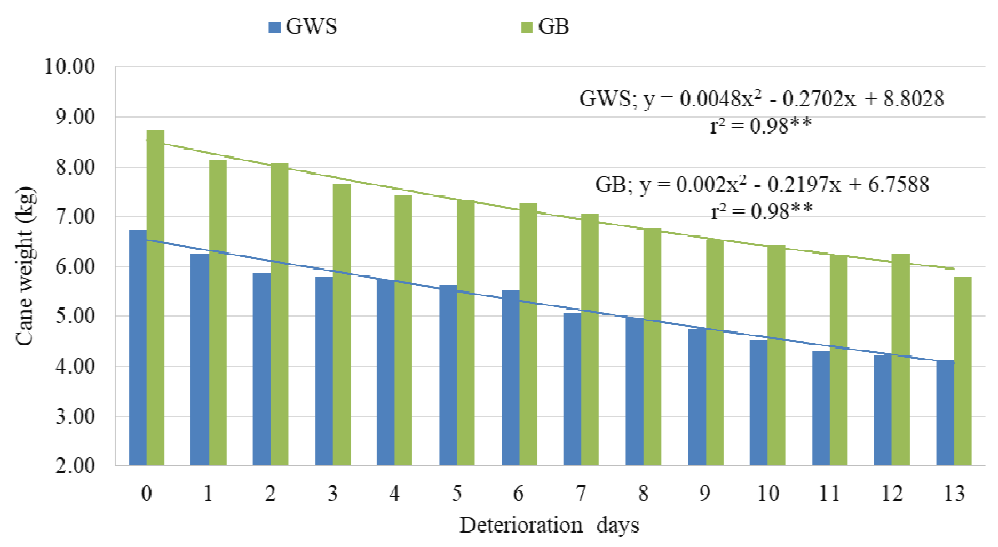

Note: * and ** indicate that the regression is statistically significant at $5 \%$ and $1 \%$, respectively. 
Table 1 Temperature and rainfall during the deterioration period

\begin{tabular}{lcccccc}
\hline \multirow{2}{*}{ Day } & $\begin{array}{c}\text { Average } \\
\text { temp. }\left({ }^{\circ} \mathrm{C}\right)\end{array}$ & $\begin{array}{c}\text { Maximum } \\
\text { temp. }\left({ }^{\circ} \mathrm{C}\right)\end{array}$ & $\begin{array}{c}\text { Minimum } \\
\text { temp. }\left({ }^{\circ} \mathrm{C}\right)\end{array}$ & $\begin{array}{c}\text { Daily rainfall } \\
(\mathrm{mm})\end{array}$ & \multicolumn{2}{c}{ Cane weight loss $(\%)$} \\
\hline 0 & 30.7 & 40.6 & 23.6 & 0 & 0 & GWS \\
1 & 34.5 & 39.2 & 29.0 & 0 & 0.8 & 1.2 \\
2 & 28.5 & 35.5 & 24.6 & 81.9 & 4.8 & 9.3 \\
3 & 27.9 & 35.7 & 22.9 & 0 & 3.9 & 4.4 \\
4 & 27.1 & 36.1 & 22.8 & 105.9 & 6.1 & 15.3 \\
5 & 26.5 & 33.6 & 22.6 & 44.1 & 3.5 & 10.9 \\
6 & 27.2 & 33.7 & 22.8 & 6.3 & 2.2 & 7.7 \\
7 & 29.0 & 37.9 & 21.9 & 0 & 4.2 & 5.7 \\
8 & 30.3 & 37.3 & 23.9 & 0 & 4.5 & 17.5 \\
9 & 28.7 & 35.9 & 24.7 & 0 & 5.3 & 21.8 \\
10 & 27.0 & 34.8 & 22.6 & 0 & 7.1 & 16.3 \\
11 & 24.7 & 29.5 & 21.4 & 0 & 6.9 & 20.8 \\
12 & 26.9 & 36.1 & 20.9 & 0 & 7.5 & 29.1 \\
13 & 29.7 & 38.7 & 23.7 & 0 & 18.3 & 36.9 \\
\hline
\end{tabular}

The effects of post-harvest delay on the weight of GWS and GB are shown in Table 1 and Figure 1. In both cases, the rate of weight decrease in GB was faster than GWS, under the same time and climatic conditions. On average, the weight of GWS and GB decreased by $18.3 \%$ and $36.9 \%$, respectively, over 13 days. GB lost more water because of the large surface area created by the mechanical harvesting method, which had an effect on the weight loss in GB. Lionnet (1996) and Corcodel and Mullet (2007) also have reported weight losses in sugarcane deterioration by means of dehydration. The weight loss in different types of harvesting was confirmed by Datir and Joshi (2015) who reported a sugarcane weight reduction of $8.9 \%$ and $30.0 \%$ over 72 hours in whole manual sugarcane and mechanical harvesting, respectively. Furthermore, Elfadil and Mohamed (2015) have also found between 24 to 72 hours of deterioration time caused weight loss of sugarcane stalk.

\subsection{Juice purity $\%$ and commercial cane sugar $\%$}

As shown in Figures 2 and 3, both juice purity \% and commercial cane sugar (CCS) \% observed a downward trend with increasing deterioration days. The weather condition was appropriate for the bacteria growth which caused a decrease of sucrose content in sugarcane stalk. Eggleston (2002) found a large drop in juice purity with deterioration time under certain environmental conditions. As expected in this study, the rate of GB deterioration was faster than GWS. Furthermore, the drop in the purity of GB showed a nearly linear trend with respect to deterioration time from $88.0 \%$ to $27.1 \%$ after 13 days. In GWS, the purity value dropped from $88.8 \%$ to about $56.3 \%$ during the same deterioration period, as shown in Figure 2. Purity drop has been reported in sugarcane deterioration by Datir and Joshi (2015) who reported sugarcane stalling in GWS and GWS from 0 to 72 hours and found that purity drop from $13 \%-15 \%$. The result indicates 
the effect sucrose content in different harvesting methods has on bacterial activity and inversion of sucrose content in sugarcane stalk.

Figure 2 Relationship between juice purity (\%) and post-harvest deterioration days (see online version for colours)

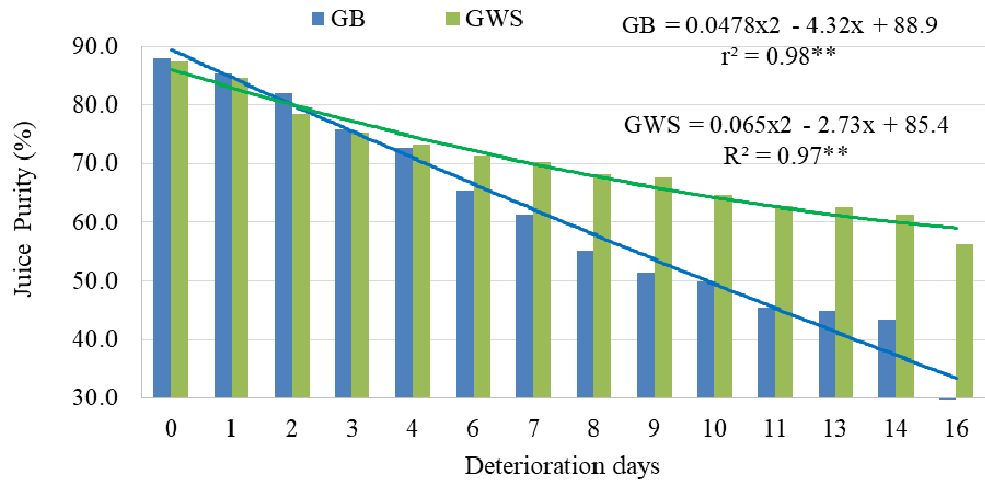

Note: * and ** indicate that the regression is statistically significant at $5 \%$ and $1 \%$, respectively.

Figure 3 Relationship between CCS \% and post-harvest deterioration days (see online version for colours)

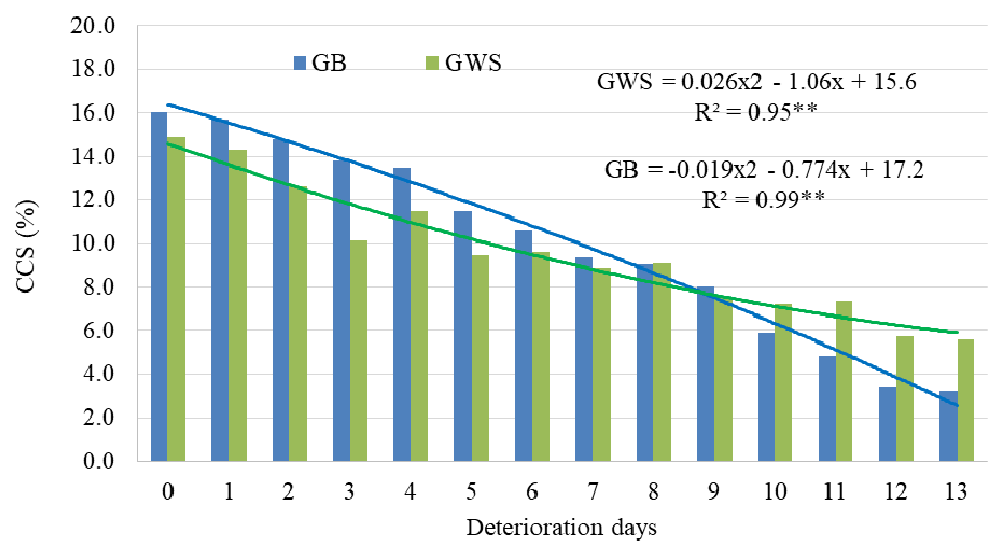

Note: * and ** indicate that the regression is statistically significant at $5 \%$ and $1 \%$, respectively.

CCS $\%$ is an approximate parameter to evaluate sucrose content in sugarcane and payment system in Thailand sugar factory. The result in Figure 3 showed the relationship between $\mathrm{CCS} \%$ and post-harvest deterioration time, which revealed high correlation between CCS \% and deterioration days, GB $\left(\mathrm{r}^{2} 0.99, p<0.001\right)$ and GWS $\left(\mathrm{r}^{2} 0.95\right.$, $p<0.001)$. The results showed a linear decrease in CCS \% with regard to post-harvest deterioration time. The percentage of CCS decreased by $5 \%$ and $4 \%$ per deterioration day for GB and GWS, respectively. High temperatures and humidity occur during Thailand's sugar cane crushing season which has an effect on cane juice quality. Period of cut to crush is very important for cane quality and sugar factory efficiency improvement. 
However, the cut to crush period processing is difficult to control because of variation in the environment, rainfall pattern, maximum and minimum temperature of the day.

\subsection{Mannitol, dextran and lactic acid}

Sucrose, glucose and fructose and mannitol (g/100 g juice) content in sugarcane juice were analysed by a HPLC. The retention time of analysis peaks was shown in Figure 4.

Figure 4 Chromatograms of sucrose, glucose, fructose and mannitol as determined by a HPLC using a Sugar Pak column by refractive index detector, retention time 8.174 minute $=$ sucrose (1), 9.999 minute $=$ glucose (2), 11.911 minute $=$ fructose (3), 14.337 minute $=$ mannitol (4), and 16.583 minute $=$ sorbitol, internal standard (5) (see online version for colours)

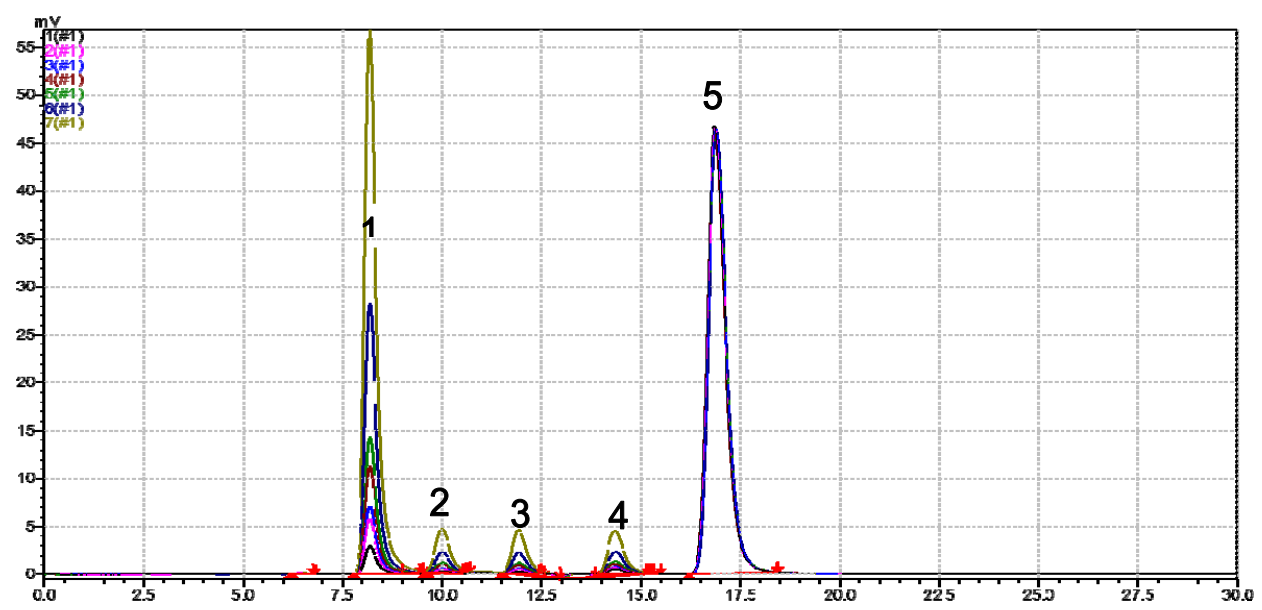

Figure 5 Relationship between mannitol, dextran and lactic acid in GB and post-harvest deterioration days

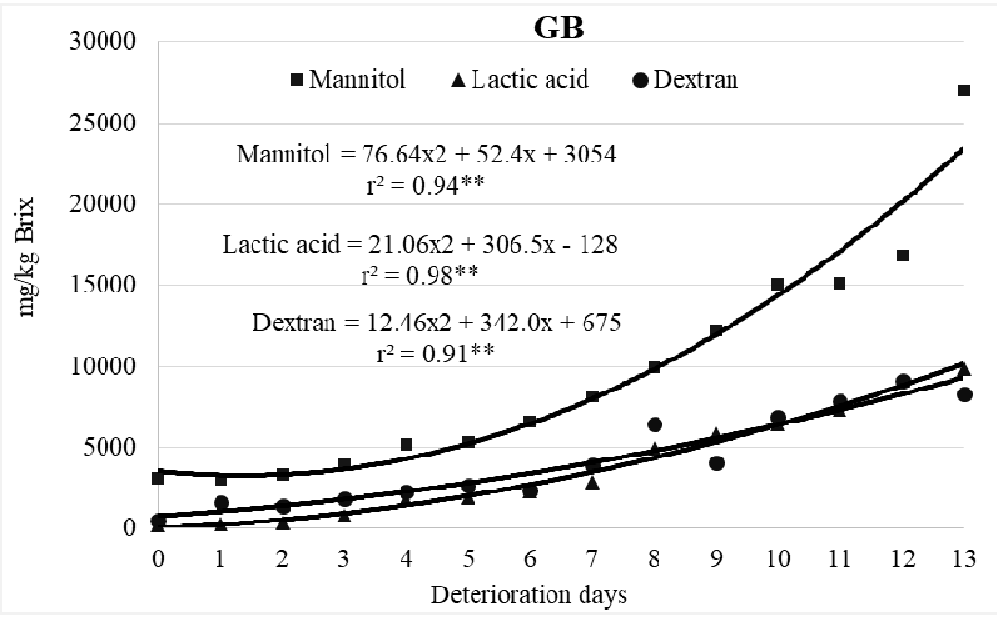

Note: $*$ and $* *$ indicate that the regression is statistically significant at $5 \%$ and $1 \%$, respectively. 
Figure 6 Relation between mannitol, dextran and lactic acid in GWS and post-harvest deterioration days

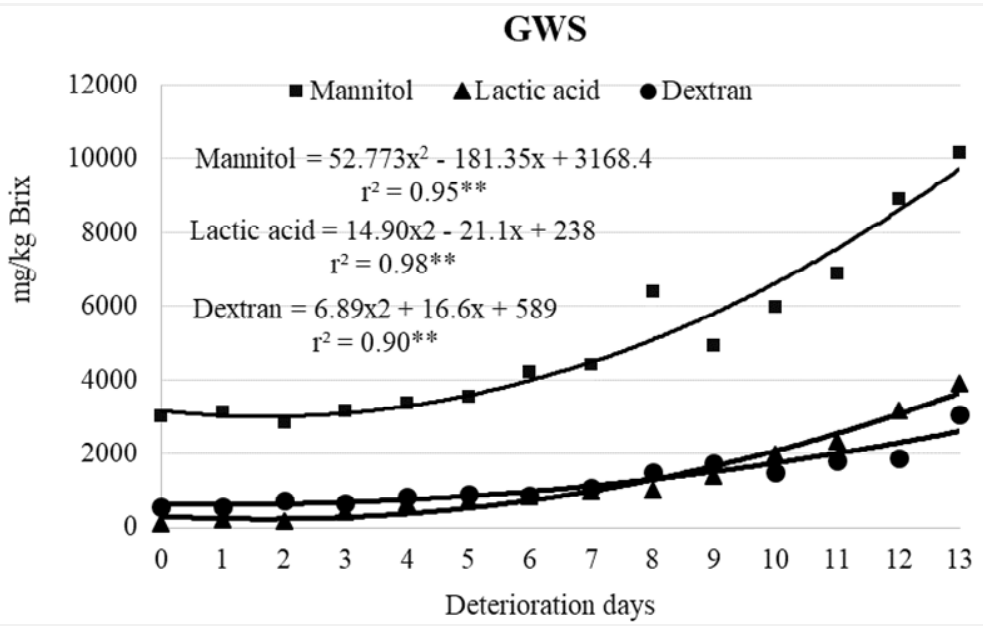

Note: * and ** indicate that the regression is statistically significant at $5 \%$ and $1 \%$, respectively.

The relationship between deterioration days and mannitol, lactic acid and dextran of GWS and of GB shown in Figures 5 and 6.

\subsubsection{Mannitol and dextran}

The concentration of mannitol increased for both GB and GWS. The manitol value increased from about 3,096 $\pm 120 \mathrm{mg} / \mathrm{kg}$ Brix to $10,189 \pm 1,469 \mathrm{mg} / \mathrm{kg}$ Brix and about $3,127 \pm 139 \mathrm{mg} / \mathrm{kg}$ Brix to $27,023 \pm 641 \mathrm{mg} / \mathrm{kg}$ Brix for GB and GWS, respectively.

The concentration of dextran in 13 days changed for both GB and GWS from 537 to $8,331 \mathrm{mg} / \mathrm{kg}$ Brix and 574 to 3,057 mg/kg Brix, respectively. Singh and Solomon (2013) have reported an increase in dextran from $5,000 \mathrm{mg} / \mathrm{kg}$ Brix in 0 days to 40,000 after ten delay days, under high temperatures. The dextran trends here appeared different from those in the literature probably due to the differences in climatic conditions and geographical locations. The data are shown in Figures 5 and 6.

The mannitol content in sugarcane juice showed an increasing trend similar to earlier reports by Singh and Solomon (2013), who studied sugarcane juice composition including mannitol formation under sub-tropical and extreme weather conditions in India during the harvesting period. They found that dextran content increased three times, while mannitol increased four times after 240 hours harvesting at $7^{\circ} \mathrm{C}$ in December. The dextran and mannitol increased by 5 and 6 times, respectively at $40^{\circ} \mathrm{C}$ in April.

\subsubsection{Lactic acid}

Lactic acid (g/100 g juice) content in sugarcane juice was analysed by a HPLC. The retention time of analysis peaks was shown in Figure 7. 
Figure 7 Chromatograms of lactic acid as determined by a HPLC using a waters C18 column by refractive index detector, retention time 13.056 minute $=$ lactic acid (1) (see online version for colours)

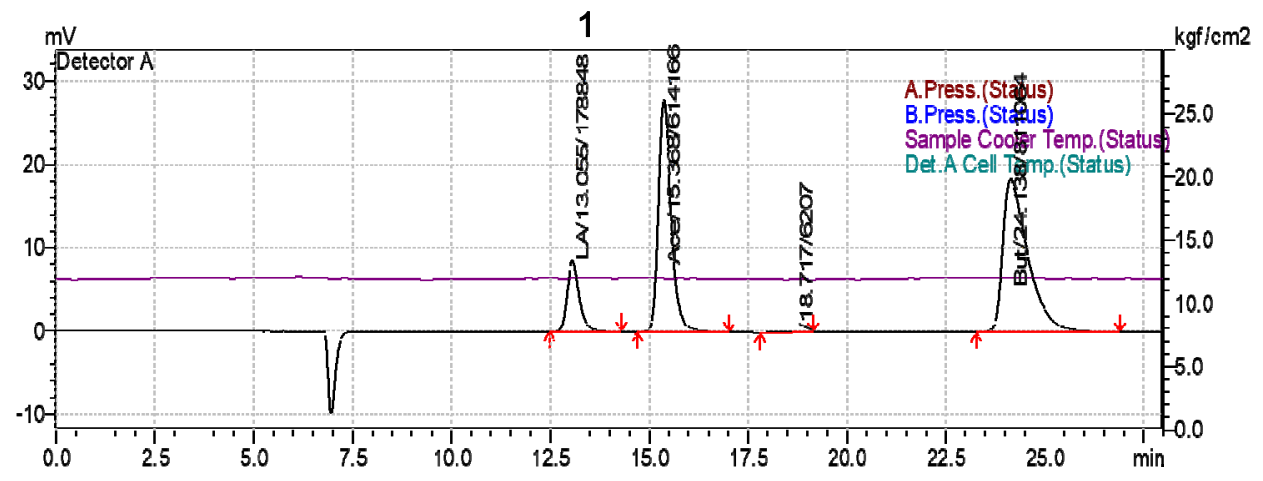

The concentration of lactic acid increased for both GB and GWS as shown in Figures 5 and 6. However, the lactic acid concentration in fresh sugarcane was close to zero, this being an advantage when investigating post-harvest deterioration. For both GB and GWS, the values were lower at the early stages and gradually increased during most of the deterioration period, with a high increase in day 13, the last day of the period. Eggleston and Huet (2012) reported lactic acid in deterioration of sugarcane which showed a good relationship with the activity of Leuconostoc bacteria. The relationship between mannitol and lactic acid was statistically significant.

\subsection{Relationship between juice purity and the concentrations of mannitol, lactic acid and dextran}

The relation between juice purity of GB and GWS, and concentrations of mannitol, lactic acid and dextran are shown in Figure 8. For both GB and GWS, the mannitol and lactic acid correlate better with juice purity than dextran. In addition, the relationship showed very highly statistical significant between mannitol and deterioration days $\left(\mathrm{r}^{2}\right.$ 0.94, $p<0.001)$, lactic acid $\left(\mathrm{r}^{2} 0.90, p<0.001\right)$ and dextran $\left(\mathrm{r}^{2} 0.83, p<0.001\right)$. This confirms the suitability of mannitol and lactic acid for estimating the purity drop during post-harvest sugarcane deterioration in Northeast Thailand. This result is in line with studies by Walford and Nel (2010) on the relationship between lactic acid, mannitol and dextran in mixed juice from sugar factory and found that both mannitol and lactic acid were possible indictors to monitor sugarcane deterioration in Northeast Thailand climatic conditions.

\subsection{RS \% Brix}

The result in Figure 9 showed that RS \% Brix increased for both GB and GWS. The RS $\%$ Brix increased from 5.2 to 56.3 and 6.8 to $39.1 \mathrm{~g} / 100 \mathrm{~g}$ Brix in GB and GWS, respectively. The shorter length of chopped sugarcane made it easier for bacteria to infect under the climatic condition of the study. The results showed the GB deteriorated faster than GWS. Previous studies by Eggleston (2002) on sucrose inversion in untreated juice revealed a strong decrease in sucrose within the first 14 hours by $29 \%$ inversion 
loss to reducing sugar. In addition, microbiological activities are the major cause of post-harvest sucrose losses in sugarcane.

Figure 8 Relationship between juice purity and the concentrations of mannitol, lactic acid and dextran in GB and GWS

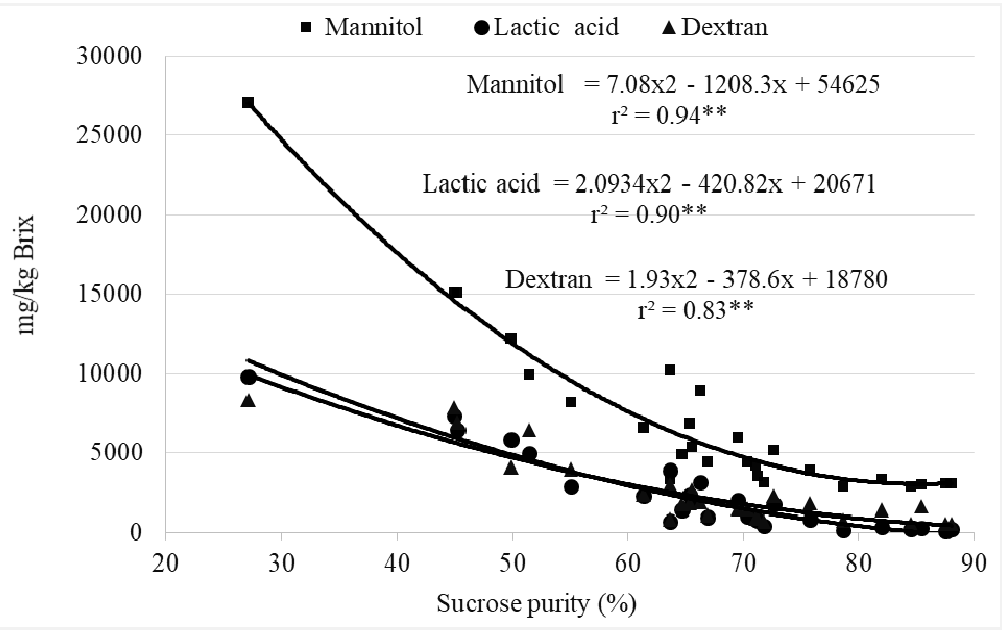

Figure 9 Relationship between RS \% Brix and post-harvest deterioration days in GB and GWS

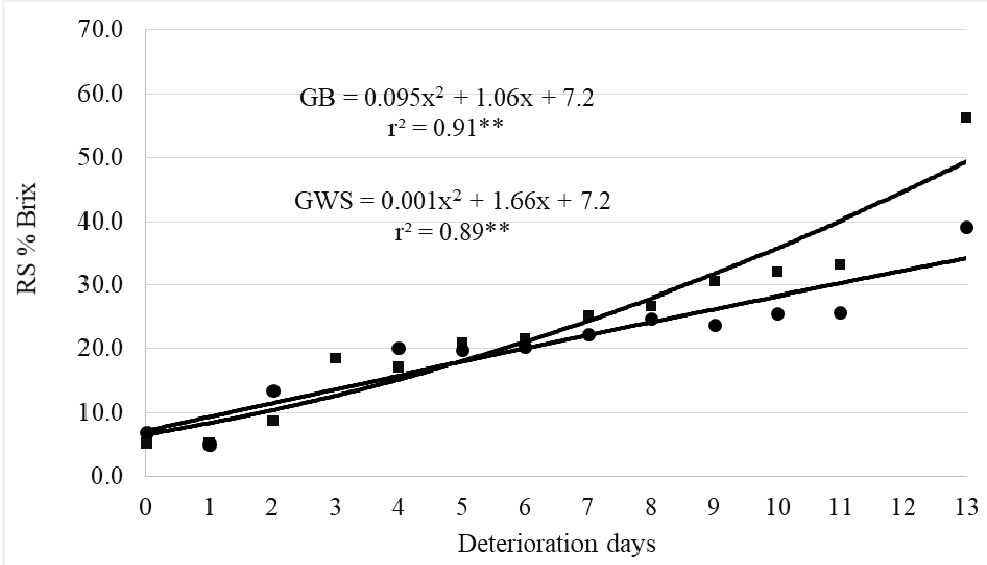

\section{Conclusions}

This study indicated that temperature, rainfall and surface area for the harvesting method of sugarcane in GB has an effect on its deterioration condition which was faster than GWS under identical conditions. The relationship between mannitol, lactic acid, and dextran in GB and GWS, the post-harvest deterioration time and purity are also the main factors for the post-harvest cane deterioration. There is no doubt that post-harvest cane deterioration causes serious negative effects on sugarcane quality not only decreases the 
sucrose content but also increases the concentrations of many non-sugar species which are known to reduce the recovery of sugar in the factory. The study results have clearly demonstrated the deterioration of cane, and the sugarcane quality should be monitored thoroughly during the sugar factories crushing season. The logistic period benchmarked of sugarcane cut to crush strategy for GWS sugarcane should control post-harvest delays within 48 hours and 24 hours for chopped cane by the involved factories. A good farmers' practice including the control of period from the sugarcane harvesting to sugarcane crushing must be practiced. The increase in production efficiency especially by supporting sugarcane and sugar processing would be one of the main feedstock for bio-economy growth. The study outcomes from this study will be useful for Thailand and elsewhere in a similar environment.

\section{Acknowledgements}

The authors are grateful to the Mitr Phol Group, Department of Biotechnology, Faculty of Agro-Industry, Kasetsart University for providing access to laboratory equipment and instruments. This work was financed by the Mitr Phol Group and Research and Researchers for Industries - RRI (RTF).

\section{References}

Anonymous (2018) Office of the Sugarcane and Sugar Board (OCSB), Ministry of Industry, Thailand [online] http://www.ocsb.go.th/upload/journal/fileupload/923-3254.pdf (accessed 24 December 2019).

Bhatia, S., Uppal, S.K., Thind, K.S. and Batta, S.K. (2009) 'Post harvest quality deterioration in sugarcane under different environmental conditions', Sugar Tech Journal, Vol. 11, No. 2, pp.154-160.

Corcodel, L. and Mullet, T. (2007) 'Aconitic acid ratio as a post-harvest whole-stalk green sugarcane age indicator', Proceedings of International Society of Sugar Cane Technologists, Vol. 26, pp.1533-1542.

Datir, S. and Joshi, S. (2015) 'Post harvest sugarcane quality under manual (whole sugarcane) and mechanical (billet) harvesting', International Journal of Current Microbiology and Applied Sciences, Vol. 4, No. 9, pp.204-218.

Eggleston, G. (2002) 'Deterioration of sugarcane juice-sources and indicators', Food Chemistry, Vol. 78, No. 1, pp.95-103.

Eggleston, G. and Huet, J.M. (2012) 'The measurement of mannitol in beet sugar factories to monitor deterioration and processing problems', Zuckerindustrie - Sugar Industry, Vol. 137, No. 1, pp.33-39.

Eggleston, G. and Legendre, B. (2003) 'Mannitol and oligosaccharides as new criteria for determining cold tolerance in sugarcane varieties', Food Chemistry, Vol. 80, No. 4, pp.451-461.

Eggleston, G. and Monge, A. (2005) 'Optimization of sugarcane factory application of commercial dextranases', Process Biochemistry, Vol. 40, No. 5, pp.1881-1894.

Eggleston, G., Morel du Boil, P.G. and Walford, S.N. (2008) 'A review of sugarcane deterioration in the United States and South Africa', Proceedings of the South African Sugar Technologists Association, Vol. 81, pp.72-85.

Elfadil, A.D. and Mohamed, M.K. (2015) 'Effect of dry-off period and crushing and extracting delays on sugarcane quality and productivity', Transactions on Industrial, Financial and Business Management, Vol. 3, No. 5, pp.67-72. 
International Commission for Uniform Methods of Sugar Analysis (ICUMSA) (1994) Method Book, with First Supplement, 1998, Publication Department, c/o British Sugar technical Centre, Norwich Research Park, Colney, UK.

Lionnet, G.R.E. (1986) 'Post-harvest deterioration of whole stalk sugarcane', Proceedings of South African Sugar Technologists Association, Vol. 60, pp.52-57.

Lionnet, G.R.E. (1996) 'Sugarcane deterioration', Proceedings of the South African Sugar Technologists Association, Vol. 70, pp.287-289.

Petit, A., Roussel, C. and Corcodel, L. (2009) 'Whole stalk green sugarcane deterioration indicators to assess mixed juice quality', Proceedings of South African Sugar Technologists Association, Vol. 82, pp.200-213.

Singh, P. and Solomon, S. (2013) 'Mannitol and dextran as indicators in assessing post harvest sugarcane quality under sub-tropical conditions', Proceedings of International Society of Sugar Cane Technologists, Vol. 28.

Solomon, S. (2009) 'Post-harvest deterioration of sugarcane', Sugar Tech Journal, Vol. 11, No. 2, pp.109-123.

Sukyai, P., Yingkamhaeng, N., Lam, N.T., Tangsatianpan, V., Watcharinrat, C., Vanitjinda, G., Vanichsriratana, W. and Sriroth, K. (2016) 'Research and development prospects for sugarcane and sugar industry in Thailand', Sugar Tech Journal, Vol. 18, No. 6, pp.583-587.

Walford, S.N. and Nel, S. (2010) 'Are mannitol and lactic acid indicators of sugar cane deterioration in a South African context?', Proceedings of the South African Sugar Technologists Association, Vol. 83, pp.410-421. 